\title{
Drying kinetics modeling of apple and zucchini slices vacuum impregnated with anthocyanins
}

\section{Luz Marina Zapata ${ }^{1^{*}}$ Juan Manuel Castagnini ${ }^{1}$ (D) Carlos Fabio Quinteros ${ }^{1}$ Mariana Jimenez Veuthey ${ }^{1}$ (iD}

${ }^{1}$ Facultad de Ciencias de la Alimentación, Universidad Nacional de Entre Ríos, 3200, Concordia, Entre Ríos, Argentina. E-mail: zapatam@fcal.uner.edu.ar. ${ }^{*}$ Corresponding author.

ABSTRACT: The aim of this research was to study the drying kinetics of apple and zucchini slices enriched with anthocyanins and to evaluate the influence of drying temperature on the anthocyanin content of apple and zucchini snacks. Apple (Granny Smith) and zucchini (Cucurbita pepo) slices were enriched with anthocyanins by vacuum impregnation with blueberry juice. Then, slices were dehydrated at 40 , 50 and $60{ }^{\circ} \mathrm{C}$ with $1.0 \mathrm{~m} / \mathrm{s}$ air flow. Dehydrated samples were referred to as anthocyanin enriched snacks. Diffusion coefficient values improved by increasing the drying temperature, within the $2.81 \times 10^{-10}$ to $5.78 \times 10^{-10} \mathrm{~m}^{2} / \mathrm{s}$ range for apple slices and $2.02 \times 10^{-10}$ to $3.99 \times 10^{-10} \mathrm{~m}^{2} / \mathrm{s}$ for $\mathrm{zucchini}$ slices. The activation energy was $31.19 \mathrm{~kJ} / \mathrm{mol}$ and $80.33 \mathrm{~kJ} / \mathrm{mol}$ for apple and zucchini slices respectively. Page, Weibull, Logarithmic, HendersonPabis and Lewis models best fitted the experimental data. Snacks obtained at $60^{\circ} \mathrm{C}$ retained a higher concentration of anthocyanins, reaching values of $592.81 \pm 52.55$ and $464.62 \pm 48.44 \mathrm{mg}$ of cyaniding-3-glucoside equivalent/kg dry matter in apple and zucchini snacks respectively. Combination of vacuum impregnation and hot air drying was a technological alternative for producing snacks with functional properties. Key words: drying kinetics, mathematical modeling, functional snacks, anthocyanins.

Modelagem da cinética de secagem de discos de maçã e abobrinha impregnadas a vácuo com antocianinas

RESUMO: $O$ objetivo deste trabalho foi estudar a cinética de secagem de fatias de maçã e abobrinha enriquecidas com antocianinas e avaliar a influência da temperatura de secagem no teor de antocianinas de discos de maçã e abobrinha. Fatias de maçã (Granny Smith) e abobrinha (Cucurbita pepo) foram enriquecidas com antocianinas por impregnação a vácuo com suco de mirtilo. Em seguida, as fatias foram desidratadas a 40, 50 e $60{ }^{\circ} \mathrm{C}$ com fluxo de ar de $1,0 \mathrm{~m} / \mathrm{s}$. As amostras desidratadas foram referidas como snacks enriquecidos com antocianinas. Os valores do coeficiente de difusão melhoraram com o aumento da temperatura de secagem, na faixa de $2.81 \times 10^{-10}$ a $5.78 \times 10^{-10} \mathrm{~m}^{2} / \mathrm{s}$ para fatias de maçã e $2.02 \times 10^{-10}$ a $3.99 \times 10^{-10} \mathrm{~m}^{2} / \mathrm{s}$ para fatias de abobrinha. A energia de ativação foi $31.19 \mathrm{~kJ} /$ mol e $80.33 \mathrm{~kJ} / \mathrm{mol}$ para as fatias de maçã e abobrinha, respectivamente. Os modelos de Page, Weibull, Logarithmic, Henderson-Pabis e Lewis ajustaram os dados experimentais. Os snacks obtidos a $60^{\circ} \mathrm{C}$ retiveram uma maior concentração de antocianinas, atingindo valores de $592.81 \pm 52.55$ e $464.62 \pm 48.44 \mathrm{mg}$ de equivalentes de cianidina-3-glicosídeo / kg de matéria seca nos snacks de maçã e abobrinha, respectivamente. A combinação da impregnação a vácuo e secagem por ar quente foi uma alternativa tecnológica para produção de lanches com propriedades funcionais.

Palavras-chave: cinética de secagem, modelagem matemática, snacks funcionais, antocianinas.

\section{INTRODUCTION}

Fruits and vegetables contain several antioxidant components with beneficial health effects (PEREIRA KECHINSKI et al., 2010). Anthocyanins are antioxidant pigments that can be added to other foods to enhance antioxidant properties (DEĞIRMENCIOĞLU et al., 2017). Bioactive components may be integrated into food porous structure, such as fruit and vegetable slices (MARTELO C; et al. 2011), by vacuum impregnation.
However, high moisture content, microbiological spoilage, and degradation of chemical reactions decrease product shelf life.

The main objective of dehydration is the removal of water in order to minimize microbial spoilage and deterioration reactions (COSTA et al., 2016; LÓPEZ et al., 2010), and thus extend food shelf life. However, the temperature increase may affect anthocy an instability (PERON et al., 2017).

Controlling drying temperature represents a challenge due to a complex system involving 
simultaneous heat and mass transfer phenomena (DI SCALA\& CRAPISTE, 2008). Thus, by carefully selecting this variable value, the product quality may increase leading to an extended bioavailability of fruit original components (LÓPEZ et al., 2010).

Mathematical models are useful for analyzing mass transfer phenomena and drying kinetics (TAGHIAN DINANI et al., 2014). In addition, they are important tools for improving drying processes and minimizing operative problems such as product damage and excessive consumption of energy, among others (VEGA-GÁLVEZ et al., 2012).

The equations frequently used to model drying kinetics are Newton, Henderson-Pabis, modified Henderson-Pabis, Page, modified Page, Logarithmic and Weibull. Most of these equations have been derived from Fick's second law of diffusion for different geometries (CORZO et al., 2008; PUENTE-DÍAZ et al., 2012; TAGHIAN DINANI et al., 2014; VEGA-GÁLVEZ et al., 2012).

The purposes of this study were to investigate the effect of drying air temperature on anthocyanin enriched apple and zucchini slices applying five thin-layer models to the experimental data and evaluate the influence of drying temperature on apple and zucchini anthocyanin content of snacks.

\section{MATERIALS AND METHODS}

\section{Raw material}

Apples (Granny Smith) and zucchinis (Cucurbita pepo) were purchased from a local market in the municipality of Concordia (Argentina). They were washed by hand, drained, peeled and cut into 60 $\mathrm{mm}$ external diameter slices, $23 \mathrm{~mm}$ internal diameter and $5 \mathrm{~mm}$ thickness. Then, slices were vacuum impregnated, dried and packaged in polypropylene bags for further physicochemical analysis.

Blueberry juice was obtained by a depectinization process as described by CASTAGNINI et al. (2017). Briefly, blueberries were washed and then crashed with a food processor. The enzymatic depectinization was carried out for $78 \mathrm{~min}$ at $50^{\circ} \mathrm{C}$ with $4 \mathrm{mg}$ of Lafase ${ }^{\circledR}$ Clarification for $100 \mathrm{~g}$ of blueberries and $8 \mathrm{mg}$ of Lafase ${ }^{\circledR} \mathrm{He}$ Grand Cru for $100 \mathrm{~g}$ of blueberries. Finally, the blueberry juice was filtered by a $0.5 \mathrm{~mm}$ sieve and pasteurized at $77 \pm 1^{\circ} \mathrm{C}$ for $85 \mathrm{~s}$.

\section{Vacuum impregnation}

Vacuum impregnation was carried out in an impregnation chamber (Vacuum Oven DZF6020, China) at $25{ }^{\circ} \mathrm{C}$. The sample was immersed in the impregnation medium (blueberry juice) in order to incorporate anthocyanins to the food matrix. Fifty mbar vacuum pressure was applied for 10 minutes, then atmospheric pressure was restored. Samples were allowed to rest in the blueberry juice for 10 minutes more.

Air drying

Hot air drying was performed in a convective dryer (4554 FAC) in the pilot plant (in triplicate). Slices were dried at 40,50 and $60{ }^{\circ} \mathrm{C}$, at $1.0 \mathrm{~m} / \mathrm{s}$ air flow rate and $50 \%$ relative humidity. Moisture loss was estimated with sample weights which were determined at $30 \mathrm{~min}$ regular intervals during drying using a balance (NJW Moretti) with $\pm 0.01 \mathrm{~g}$ accuracy until reaching constant weight (equilibrium condition). Drying time was $10 \mathrm{~h}$ at 40 and $50{ }^{\circ} \mathrm{C}$ and $8 \mathrm{~h}$ at $60^{\circ} \mathrm{C}$. Dehydrated samples were referred to as anthocyanin enriched snacks.

\section{Water diffusion coefficient}

Fick's second diffusion law was used to study mass transfer phenomena during the dehydration of apple and zucchini slices. In this model, the dependent variable is the moisture ratio (MR, dimensionless) which relates the gradient of the sample moisture content at any time of drying $\left(\mathrm{M}_{\mathrm{t}}, \mathrm{kg}\right.$ water/kg dry matter) to both initial moisture content $\left(\mathrm{M}_{0}, \mathrm{~kg}\right.$ water $/ \mathrm{kg}$ dry matter $)$ and equilibrium moisture content $\left(\mathrm{M}_{\mathrm{e}}, \mathrm{kg}\right.$ water $/ \mathrm{kg}$ dry matter $)$, Equation 1 (OLANIPEKUN et al., 2014)

$$
M R=\frac{\mathrm{M}_{\mathrm{t}}-\mathrm{M}_{\mathrm{e}}}{\mathrm{M}_{\mathrm{o}}-\mathrm{M}_{\mathrm{e}}}
$$

The solution of the diffusion equation for an infinite lamina was given by CRANK (1979) and uniform initial moisture distribution, negligible external resistance, constant diffusivity, and negligible shrinkage were estimated (Equation 2) (JUNQUEIRA et al., 2017).

$\mathrm{MR}=\frac{8}{\pi^{2}} \sum_{\mathrm{n}=0}^{\infty} \frac{1}{(2 \mathrm{n}-1)^{2}} \cdot \mathrm{e}^{\left[-(2 \mathrm{n}-1)^{\frac{\pi^{2} \mathrm{D}}{4 \mathrm{~L}^{2}}}\right]}$

where: $\mathrm{D}_{\text {eff }}$ is the effective diffusivity $\left(\mathrm{m}^{2} / \mathrm{s}\right)$, $\mathrm{t}$ is time $(\mathrm{h}), \mathrm{L}$ is sample half-thickness $(\mathrm{m})$ and $\mathrm{n}$ is the number of terms.

For long drying times, only the first term in Equation 2 is significant and the equation was simplified as described by some researchers (DOYMAZ et al., 2016).

$\mathrm{MR}=\frac{8}{\pi^{2}} \cdot e^{\left[\frac{\pi^{2} D_{\text {eff }} t}{4 L^{2}}\right]}$

Equation 3 can be written in a logarithmic form as follows:

$$
\operatorname{In}(\mathrm{MR})=\operatorname{In}\left(\frac{8}{\pi^{2}}\right)-\left(\frac{\pi^{2} D_{e f f^{t}}}{4 L^{2}}\right)
$$


Effective moisture diffusivity values were determined by plotting experimental drying data, the logarithm of MR versus drying time.

\section{Activation energy}

The activation energy was calculated using an Arrhenius type equation (Equation 5), plotting the natural logarithm of $\mathrm{D}_{\text {eff }}$ against the reciprocal of absolute temperature (Equation 6) (JUNQUEIRA et al., 2017; OLANIPEKUN et al., 2014).

$$
\begin{aligned}
& D_{\text {eff }}=D_{0} \cdot e^{-\frac{E_{a}}{R \cdot T}} \\
& \text { In }\left(D_{\text {eff }}\right)=\operatorname{In} D_{o}-\frac{E_{a}}{R \cdot T}
\end{aligned}
$$

where: $\mathrm{E}_{\mathrm{a}}$ is activation energy $(\mathrm{kJ} / \mathrm{mol}), \mathrm{D}_{0}$ is the preexponential factor of the Arrhenius equation $\left(\mathrm{m}^{2} / \mathrm{s}\right), \mathrm{R}$ is the universal gas constant $(8.3143 \mathrm{~kJ} / \mathrm{mol} \mathrm{K})$ and $\mathrm{T}$ is the absolute air temperature $(\mathrm{K})$.

\section{Mathematical modeling of drying kinetics}

Drying kinetics was modeled using five empirical equations: Newton, Henderson-Pabis, Page, Logarithmic, and Weibull (Table 1).

\section{Quality parameters}

Moisture content was determined according to AOAC Official Method 934.06 in a vacuum drying oven at $70{ }^{\circ} \mathrm{C}$ until constant weight (AOAC. ASSOCIATION OF OFFICIAL ANALYTICAL CHEMISTS, 2010).

Total anthocyanin content (TA) was determined by the $\mathrm{pH}$ differential method (ZHAO et al., 2008). One gram of anthocyanin enriched apple or zucchini slices were extracted three times using acidified methanol with hydrochloric acid $(1 \% \mathrm{w} / \mathrm{v})$. Extracts were centrifuged at 4000 r.p.m. for $10 \mathrm{~min}$. Two aliquots of the supernatant were diluted to $1: 10$ in $0.025 \mathrm{M} \mathrm{KCl}$ at $\mathrm{pH} 1$ and in $0.4 \mathrm{M} \mathrm{CH}_{3} \mathrm{COONa}$ at $\mathrm{pH}$ 4.5. Absorbance was measured using a spectrophotometer (HACH DR600, USA) at 510 and $700 \mathrm{~nm}$ against a blank cell filled with distilled water. Total anthocyanin content was calculated according to the following formulas and expressed as mg of cyanidin 3-glucoside equivalent/kg dry matter.

$\Delta A=\left[\left(A_{510}-A_{700}\right)\right]_{(p H=1)}-\left[\left(A_{510}-A_{700}\right)\right]_{(p H=4.5)}$

$T A=\frac{\Delta A}{\varepsilon \cdot 1} \cdot M W \cdot D \cdot \frac{V}{M} \cdot 1000$

where $\Delta \mathrm{A}$ represents change absorbance, $\mathrm{MW}$ is the molecular weight $(449.2 \mathrm{~g} / \mathrm{mol})$, D is the dilution factor, $\varepsilon$ is the cyanidin 3-glucoside molar extinction coefficient [26.900 L/(mol.cm)], 1 represents the cell path length $(1 \mathrm{~cm}), \mathrm{V}$ is final volume $(\mathrm{L}), \mathrm{M}$ is sample weight $(\mathrm{kg})$ and 1000 is the conversion factor from $\mathrm{mg}$ to $\mathrm{g}$.

\section{Statistical analysis}

All experiments were performed in triplicate. Mass transfer kinetics was modeled and compared by means of mathematical models represented in table 1 . These models were fitted against experimental data using Octave software (GNU OCTAVE 4.4.0). The goodness of fit between predicted and experimental data were evaluated using the determination coefficient $\left(\mathrm{R}^{2}\right.$, Equation 9), sum squared errors (SSE, Equation 10) and root mean sum errors (RMSE, Equation 11) where, $M R_{\text {exp, } \mathrm{i}}$ and $M R_{\text {pre, }}$ are experimental and predicted moisture ratio, respectively; $\mathrm{N}$ is observation number and $i$ is number of terms.

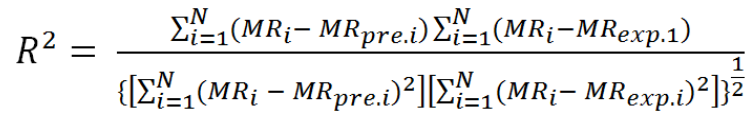

$$
\begin{aligned}
& S S E=\frac{1}{N} \sum_{i=1}^{N}\left(M R_{\text {exp. } i}-M R_{\text {pre } . i}\right)^{2} \\
& R M S E=\left[\frac{1}{N} \sum_{i=1}^{N}\left(M R_{\text {pre. } i}-M R_{\text {exp } . i}\right)^{2}\right]^{1 / 2}
\end{aligned}
$$

Table 1 - Mathematical models selected to describe apple and zucchini slices enriched with anthocyanins drying kinetics.

\begin{tabular}{lcc}
\hline Model name & Model equation & References \\
\hline Newton (Lewis) & $M R=e^{-k \cdot t}$ & (DOYMAZ; et al, 2016) \\
Henderson-Pabis & $M R=n_{1} \cdot e^{-k_{1} \cdot t}+n_{2} \cdot e^{-k_{2}}+n_{3} \cdot e^{-k_{3}}$ & (PUENTE-DíAZ et al., 2012) \\
Logarithmic & $M R=c+n \cdot e^{-k \cdot t}$ & (DOYMAZ; et al, 2016; VEGA-GÁLVEZ et al., 2012) \\
Page & $M R=c \cdot e^{-k \cdot t^{n}}$ & (DOYMAZ; et al, 2016) \\
Weibull & $M R=e^{-\left(\frac{t^{\beta}}{a}\right)}$ & (CORZO et al., 2008) \\
\hline
\end{tabular}

where: $\mathrm{MR}$ is Moisture Rate, $\mathrm{k}_{\mathrm{i}}$ is kinetics parameter $\left(\mathrm{h}^{-1}\right), \mathrm{n}_{\mathrm{i}}$ and $\mathrm{c}$ are empirical parameters (dimensionless), $\alpha$ is the scale parameter (h), $\beta$ is the shape parameter (dimensionless) and $t$ is drying time (h). 
The closest values to 1.0 for $\mathrm{R}^{2}$ and those closest to zero for SSE and RMSE were considered as optimal criteria for the quality of the models (OLANIPEKUN et al., 2014; TAGHIAN DINANI et al., 2014).

Experimental data and mathematical model parameters were analyzed using STATGRAPHICS (Statgraphics Centurion XVI v.16.1.1, USA) software, applying an analysis of variance (ANOVA) and multiple range test. Significant differences were defined at $\alpha<0.05$.

\section{RESULTS AND DISCUSSION}

\section{Influence of temperature and drying kinetics}

Apple and zucchini slices initial moisture content values were $7.50 \pm 0.10$ and $7.72 \pm 0.06 \mathrm{~kg}$ water $/ \mathrm{kg}$ dry matter, respectively. These slices were dried at 40,50 and $60{ }^{\circ} \mathrm{C}$ until a moisture content of $1.10 \pm 0.01 \mathrm{~kg}$ water $/ \mathrm{kg}$ dry matter was reached in all cases, except for the zucchini slices, dried at $60{ }^{\circ} \mathrm{C}$, that showed $0.65 \pm 0.05 \mathrm{~kg}$ water $/ \mathrm{kg}$ dry matter final humidity.

Figure 1 shows apple and zucchini slices moisture ratio versus drying time for three temperatures at $1.0 \mathrm{~m} / \mathrm{s}$ air velocity. Results indicated that an increase in drying temperature led to a decrease in the time required to achieve definite moisture content, especially when $60{ }^{\circ} \mathrm{C}$ was the drying temperature. Experimental drying curves also indicated a higher drying rate in the first hours of the process, during which internal molecular diffusion is the predominant mass transfer mechanism (PUENTEDÍAZ et al., 2012; OLANIPEKUN et al., 2014).

Estimation of the water diffusion coefficient and activation energy

Knowledge of effective diffusivities seems necessary for issues of process design, quality control, storage requirements and product transfer (BAHMANI et al., 2016). Table 2 shows that the diffusion coefficient values slightly improved when increasing process temperature. In addition, this coefficient was higher in apple slices at all temperatures, fact attributed to a lower contraction caused by the reduction of cell tissue, which affects mass and heat transfer parameters.

These values agree with those reported by VEGA-GÁLVEZ et al. (2012) for apple slices dried

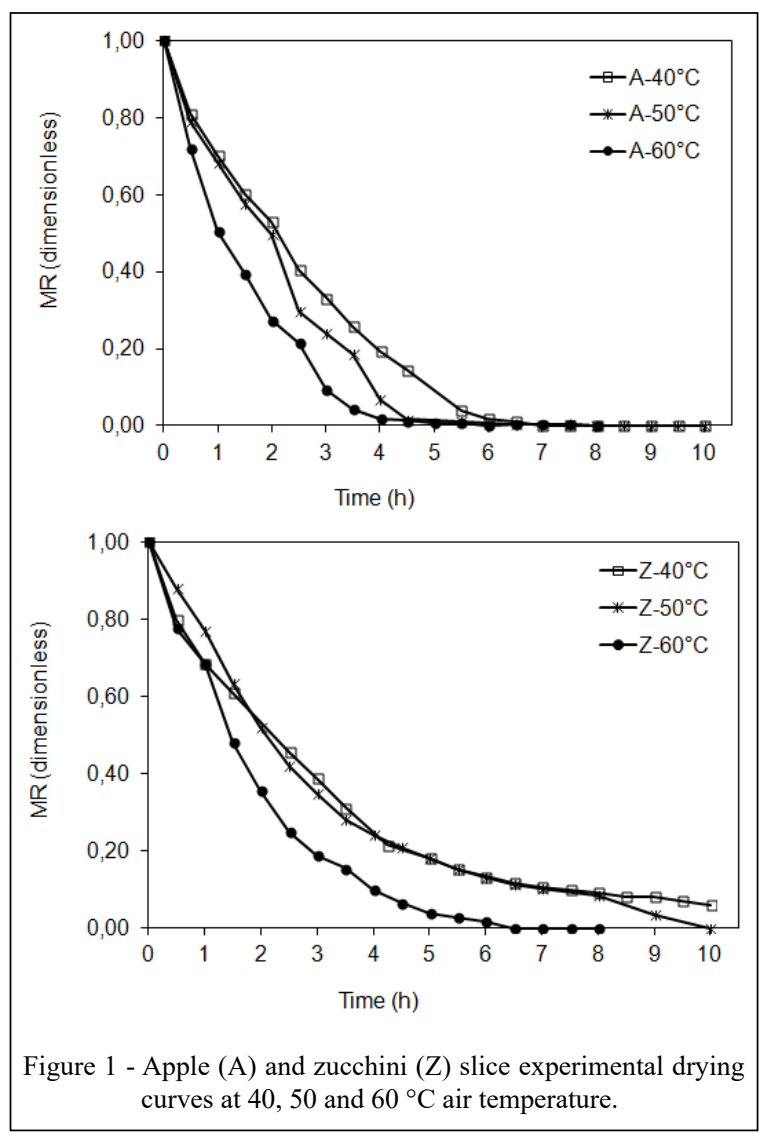

Ciência Rural, v.49, n.10, 2019. 
Table 2 - Effective moisture diffusivity values for apple and zucchini slices dried at different temperatures.

\begin{tabular}{|c|c|c|c|c|c|}
\hline & Temperature $\left({ }^{\circ} \mathrm{C}\right)$ & $D_{\text {eff }} 10^{-10}\left(\mathrm{~m}^{2} / \mathrm{s}\right)$ & SSE & $\mathrm{R}^{2}$ & RMSE \\
\hline \multirow{3}{*}{ Apple } & 40 & $2.81 \pm 0.38^{\mathrm{aB}}$ & 1.32 & 0.85 & 0.36 \\
\hline & 50 & $3.97 \pm 0.46^{\mathrm{bB}}$ & 0.66 & 0.87 & 0.33 \\
\hline & 60 & $5.78 \pm 1.26^{\mathrm{cB}}$ & 2.36 & 0.97 & 0.40 \\
\hline \multirow{3}{*}{ Zucchini } & 40 & $2.02 \pm 0.28 \mathrm{aA}$ & 1.32 & 0.85 & 0.36 \\
\hline & 50 & $2.06 \pm 0.26^{\mathrm{aA}}$ & 0.66 & 0.87 & 0.33 \\
\hline & 60 & $3.99 \pm 0.44^{\mathrm{bA}}$ & 3.26 & 0.97 & 0.47 \\
\hline
\end{tabular}

Different letters $(\mathrm{a}, \mathrm{b}, \mathrm{c})$ for the same matrix indicate that the $\mathrm{D}_{\text {eff }}$ values are significantly different. Different letters (A, B) for the same temperature indicate that the $\mathrm{D}_{\text {eff }}$ values are significantly different. SSE: sum of squared errors; $\mathrm{R}^{2}$ : determination coefficient; RMSE: root mean sum errors.

at $1.0 \mathrm{~m} / \mathrm{s}$ air velocity and 40 and $60^{\circ} \mathrm{C}$, pointing $\mathrm{D}_{\text {eff }}$ values of $3.5 \times 10^{-10}$ and $4.9 \times 10^{-10} \mathrm{~m}^{2} / \mathrm{s}$, respectively. In pumpkin slices osmotic dehydration, JUNQUEIRA et al. (2017) obtained $\mathrm{D}_{\text {eff }}$ values within $2.34 \times 10^{-10}$ to $2.87 \times 10^{-10} \mathrm{~m}^{2} / \mathrm{s}$ range when processed at 30 and $60^{\circ}$ $\mathrm{C}$ and 2.22 and $4.44 \mathrm{~m} / \mathrm{s}$ air velocities.

Natural logarithm of $\mathrm{D}_{\text {eff }}$ as a function of reciprocal of absolute temperature was plotted and the result showed that there was a linear relationship derived from the Arrhenius-type equation. Estimated activation energy was 31.19 $\mathrm{kJ} / \mathrm{mol}\left(\mathrm{R}^{2}=1.00\right)$ and $80.33 \mathrm{~kJ} / \mathrm{mol}\left(\mathrm{R}^{2}=0.98\right)$ for apple and zucchini slices, respectively. These results indicated that higher energy is required for zucchinis, when compared to apples, to initiate the moisture diffusion from the food material internal region (OLANIPEKUN et al., 2014).

Activation energy values were similar to those suggested by other authors for different plant materials: $22.828 \mathrm{~kJ} / \mathrm{mol}$ for Phyllanthus niruri and $43.129 \mathrm{~kJ} / \mathrm{mol}$ for Phyllanthusamarus (SOUSADUTRA et al., 2018), and $75.24 \mathrm{~kJ} / \mathrm{mol}$ for pineapple (TUNÇKAL et al., 2018).

\section{Mathematical modeling of drying kinetics}

Five models studied were fitted to apple and zucchini slices experimental data (moisture ratio against drying time). Table 3 shows the kinetics and

Table 3 - Coefficients of drying models for prediction of drying kinetics of apple and zucchini slices.

\begin{tabular}{|c|c|c|c|c|c|c|c|}
\hline Model & $\mathrm{P}$ & $\mathrm{A}-40^{\circ} \mathrm{C}$ & $\mathrm{A}-50^{\circ} \mathrm{C}$ & $\mathrm{A}-60^{\circ} \mathrm{C}$ & $\mathrm{Z}-40^{\circ} \mathrm{C}$ & $\mathrm{Z}-50^{\circ} \mathrm{C}$ & $\mathrm{Z}-60^{\circ} \mathrm{C}$ \\
\hline Newton (Lewis) & $\mathrm{k}$ & $0.399 \pm 0.020^{\mathrm{aA}}$ & $0.449 \pm 0.235^{\mathrm{aA}}$ & $0.690 \pm 0.035^{\mathrm{cA}}$ & $0.334 \pm 0.027^{\mathrm{aB}}$ & $0.336 \pm 0.025^{\mathrm{aB}}$ & $0.529 \pm 0.042^{\mathrm{cB}}$ \\
\hline \multirow{6}{*}{ Henderson-Pabis } & $\mathrm{k}_{1}$ & $0.298 \pm 0.020^{\mathrm{aA}}$ & $0.372 \pm 0.022^{\mathrm{bA}}$ & $0.653 \pm 0.038^{\mathrm{cA}}$ & $0.337 \pm 0.018^{\mathrm{aA}}$ & $0.355 \pm 0.021^{\mathrm{aA}}$ & $0.486 \pm 0.022^{\mathrm{cB}}$ \\
\hline & $\mathrm{n}_{1}$ & $1.140 \pm 0.049^{\mathrm{aA}}$ & $1.099 \pm 0.044^{\mathrm{aA}}$ & $1.029 \pm 0.064^{\mathrm{aA}}$ & $0.966 \pm 0.049^{\mathrm{aB}}$ & $1.027 \pm 0.085^{\mathrm{aA}}$ & $1.063 \pm 0.042^{\mathrm{aA}}$ \\
\hline & $\mathrm{k}_{2}$ & $0.547 \pm 0.027^{\mathrm{aA}}$ & $0.750 \pm 0.031^{\mathrm{bA}}$ & $0.523 \pm 0.028^{\mathrm{aA}}$ & $0.913 \pm 0.054^{\mathrm{aB}}$ & $0.693 \pm 0.036^{\mathrm{bB}}$ & $0.042 \pm 0.003^{\mathrm{cB}}$ \\
\hline & $\mathrm{n}_{2}$ & $0.265 \pm 0.017^{\mathrm{aA}}$ & $-0.031 \pm 0.002^{\mathrm{bA}}$ & $0.301 \pm 0.019^{\mathrm{aA}}$ & $0.056 \pm 0.004^{\mathrm{aB}}$ & $0.096 \pm 0.007^{\mathrm{bB}}$ & $-0.344 \pm 0.013^{c B}$ \\
\hline & $\mathrm{k}_{3}$ & $0.211 \pm 0.011^{\mathrm{aA}}$ & $0.628 \pm 0.031^{\mathrm{bA}}$ & $0.521 \pm 0.023^{\mathrm{cA}}$ & $0.456 \pm 0.029^{\mathrm{aB}}$ & $0.992 \pm 0.052^{\mathrm{bB}}$ & $0.534 \pm 0.025^{\mathrm{cA}}$ \\
\hline & $\mathrm{n}_{3}$ & $-0.366 \pm 0.020^{\mathrm{aA}}$ & $-0.143 \pm 0.011^{\mathrm{bA}}$ & $-0.338 \pm 0.019^{\mathrm{aA}}$ & $-0.015 \pm 0.001^{\mathrm{aB}}$ & $-0.108 \pm 0.004^{\mathrm{bA}}$ & $0.491 \pm 0.029^{\mathrm{cB}}$ \\
\hline \multirow{3}{*}{ Logarithmic } & $\mathrm{c}$ & $-0.143 \pm 0.009^{\mathrm{aA}}$ & $-0.091 \pm 0.004^{\mathrm{bA}}$ & $-0.023 \pm 0.001^{\mathrm{cA}}$ & $0.013 \pm 0.001^{\mathrm{aB}}$ & $0.008 \pm 0.001^{\mathrm{bB}}$ & $-0.042 \pm 0.004^{\mathrm{cB}}$ \\
\hline & $\mathrm{k}$ & $0.298 \pm 0.010^{\mathrm{aA}}$ & $0.372 \pm 0.018^{\mathrm{bA}}$ & $0.653 \pm 0.031^{\mathrm{cA}}$ & $0.337 \pm 0.002^{\mathrm{aB}}$ & $0.355 \pm 0.021^{\mathrm{aA}}$ & $0.486 \pm 0.017^{\mathrm{cB}}$ \\
\hline & $\mathrm{n}$ & $1.140 \pm 0.080^{\mathrm{aA}}$ & $1.099 \pm 0.040^{\mathrm{aA}}$ & $1.029 \pm 0.055^{\mathrm{aA}}$ & $0.966 \pm 0.059^{\mathrm{aB}}$ & $1.027 \pm 0.058^{\mathrm{aA}}$ & $1.063 \pm 0.049^{\mathrm{aA}}$ \\
\hline \multirow{3}{*}{ Page } & $\mathrm{c}$ & $0.951 \pm 0.039^{\mathrm{aA}}$ & $0.959 \pm 0.067^{\mathrm{aA}}$ & $0.988 \pm 0.060^{\mathrm{aA}}$ & $0.986 \pm 0.079^{\mathrm{aA}}$ & $1.017 \pm 0.050^{\mathrm{aA}}$ & $0.987 \pm 0.037^{\mathrm{aA}}$ \\
\hline & $\mathrm{k}$ & $0.256 \pm 0.011^{\mathrm{aA}}$ & $0.310 \pm 0.023^{\mathrm{bA}}$ & $0.627 \pm 0.046^{\mathrm{cA}}$ & $0.346 \pm 0.018^{\mathrm{aB}}$ & $0.319 \pm 0.023^{\mathrm{aA}}$ & $0.433 \pm 0.022^{\mathrm{cB}}$ \\
\hline & $\mathrm{n}$ & $1.349 \pm 0.093^{\mathrm{aA}}$ & $1.371 \pm 0.088^{\mathrm{aA}}$ & $1.130 \pm 0.056^{\mathrm{aA}}$ & $0.962 \pm 0.064^{\mathrm{aB}}$ & $1.059 \pm 0.038^{\mathrm{aB}}$ & $1.219 \pm 0.106^{\mathrm{aB}}$ \\
\hline \multirow[b]{2}{*}{ Weibull } & $\beta$ & $1.244 \pm 0.084^{\mathrm{aA}}$ & $1.276 \pm 0.072^{\mathrm{aA}}$ & $1.114 \pm 0.082^{\mathrm{aA}}$ & $0.942 \pm 0.039^{\mathrm{aB}}$ & $1.082 \pm 0.082^{\mathrm{aB}}$ & $1.198 \pm 0.084^{\mathrm{aB}}$ \\
\hline & $\alpha$ & $2.603 \pm 0.183^{\mathrm{aA}}$ & $2.254 \pm 0.116^{\mathrm{aA}}$ & $1.489 \pm 0.076^{\mathrm{cA}}$ & $2.960 \pm 0.157^{\mathrm{aA}}$ & $2.997 \pm 0.168^{\mathrm{aB}}$ & $1.960 \pm 0.063^{\mathrm{cB}}$ \\
\hline
\end{tabular}

Different letters $(a, b, c)$ for the same matrix indicate that the average values of the parameters $(P)$ at different temperatures are significantly different $(\alpha<0.05)$. Different letters $(\mathrm{A}, \mathrm{B})$ for the same temperature indicate that the average values of parameters at different matrices are significantly different $(\alpha<0.05)$. 
empirical parameter values for each evaluated drying temperature for all models.

ANOVA result was $\alpha>0.05$ for most models, representing the average of empirical parameters $\left(n_{\mathrm{r}}\right)$, thus suggesting that these parameters depend on tissue characteristics and drying air flow rather than on temperature (VEGA-GÁLVEZ et al., 2009). As for the $\beta$ shape parameter of the Weibull equation, which is related to the velocity of mass transfer during the initial drying stages, no significant difference was observed with increased drying air temperature. However, kinetic $\left(\mathrm{k}_{\mathrm{i}}\right)$ and scale $(\alpha)$ parameters statistical evaluation result was $\alpha<0.05$, indicating a significant influence of drying temperature on these parameters.

Kinetics parameter $\mathrm{k}_{\mathrm{i}}$ increased as drying temperature rose. These $\mathrm{k}_{\mathrm{i}}$ coefficients could be associated with the facility to remove moisture from the sample, and its values are related to effective moisture diffusivity (TAGHIAN DINANI et al., 2014).

Statistical results for each model are shown in table $4, \mathrm{R}^{2}, \mathrm{SSE}$, and RMSE were within 0.9782 to $0.9965,0.0045$ to 0.0350 , and 0.0184 to 0.0533 ranges, respectively for all temperatures and models. Therefore, all models accurately described impregnated apple and zucchini slice drying kinetics. Page, followed by Weibull, Logarithmic, Henderson-Pabis, and Lewis best fitted the experimental data, based on the highest $\mathrm{R}^{2}$ and lowest SSE and RMSE criteria.

\section{Total anthocyanins}

The anthocyanin content of blueberry juice was $546.45 \pm 16.23 \mathrm{mg}$ cyanidin 3-glucoside/L. After apple's vacuum impregnation, the anthocyanin concentration on the juice was $409.62 \pm 39.61 \mathrm{mg} / \mathrm{L}$. Also, after zucchini's vacuum impregnation, the anthocyanin concentration on the juice was $513.06 \pm$ $29.55 \mathrm{mg} / \mathrm{L}$. Therefore, the impregnation percentage was $28.32 \pm 3.58 \%$ for the apple and $5.53 \pm 1.72 \%$ for the zucchini.

Impregnated apple and zucchini slice total anthocyanin content did not show significant differences when compared in terms of dry matter (Figure 2). Apple snacks obtained at 40, 50 and 60 ${ }^{\circ} \mathrm{C}$ retained 57, 63 and $93 \%$ total anthocyanins, respectively; no significant differences were observed between the impregnated apple slices anthocyanin means and snacks obtained at $60{ }^{\circ} \mathrm{C}$. Conversely, zucchini snacks retained 41, 73 and $79 \%$ total anthocyanins at the same temperatures. The $60{ }^{\circ} \mathrm{C}$ treatment retained the highest anthocyanin amount. The highest concentration of total anthocyanins in snacks obtained at $60{ }^{\circ} \mathrm{C}$ was attributed to shorter drying times.

\section{CONCLUSION}

Lewis, Page, Henderson-Pabis, Logarithmic, and Weibull drying models adequately described dehydration kinetics of apple and zucchini

Table 4 - Statistical values for apple and zucchini slice drying.

\begin{tabular}{|c|c|c|c|c|c|c|c|}
\hline Model & Parameter & $\mathrm{A}-40^{\circ} \mathrm{C}$ & $\mathrm{A}-50^{\circ} \mathrm{C}$ & A- $60{ }^{\circ} \mathrm{C}$ & $\mathrm{Z}-40^{\circ} \mathrm{C}$ & $\mathrm{Z}-50^{\circ} \mathrm{C}$ & $\mathrm{Z}-60^{\circ} \mathrm{C}$ \\
\hline \multirow{3}{*}{ Newton (Lewis) } & $\mathrm{R}^{2}$ & 0.9782 & 0.9786 & 0.9925 & 0.9949 & 0.9944 & 0.9896 \\
\hline & SSE & 0.0350 & 0.0313 & 0.0107 & 0.0060 & 0.0075 & 0.0162 \\
\hline & RMSE & 0.0483 & 0.0533 & 0.0258 & 0.0208 & 0.0223 & 0.0318 \\
\hline \multirow{3}{*}{ Henderson-Pabis } & $\mathrm{R}^{2}$ & 0.9929 & 0.9811 & 0.9924 & 0.9939 & 0.9940 & 0.9926 \\
\hline & SSE & 0.0076 & 0.0151 & 0.0074 & 0.0047 & 0.0053 & 0.0079 \\
\hline & RMSE & 0.0276 & 0.0502 & 0.0260 & 0.0228 & 0.0230 & 0.0268 \\
\hline \multirow{3}{*}{ Logarithmic } & $\mathrm{R}^{2}$ & 0.9945 & 0.9874 & 0.9940 & 0.9954 & 0.9954 & 0.9942 \\
\hline & SSE & 0.0076 & 0.0151 & 0.0074 & 0.0047 & 0.0053 & 0.0079 \\
\hline & RMSE & 0.0242 & 0.0410 & 0.0231 & 0.0197 & 0.0202 & 0.0238 \\
\hline \multirow{3}{*}{ Page } & $\mathrm{R}^{2}$ & 0.9918 & 0.9897 & 0.9941 & 0.9956 & 0.9961 & 0.9964 \\
\hline & SSE & 0.0131 & 0.0123 & 0.0073 & 0.0045 & 0.0045 & 0.0049 \\
\hline & RMSE & 0.0318 & 0.0370 & 0.0228 & 0.0193 & 0.0185 & 0.0187 \\
\hline \multirow{3}{*}{ Weibull } & $\mathrm{R}^{2}$ & 0.9893 & 0.9894 & 0.9944 & 0.9957 & 0.9961 & 0.9965 \\
\hline & SSE & 0.0159 & 0.0141 & 0.0074 & 0.0047 & 0.0048 & 0.0051 \\
\hline & RMSE & 0.0337 & 0.0376 & 0.0223 & 0.0190 & 0.0185 & 0.0184 \\
\hline
\end{tabular}

$\mathrm{R}^{2}$ : determination coefficient; SSE: sum of squared errors; RMSE: root mean sum errors. 


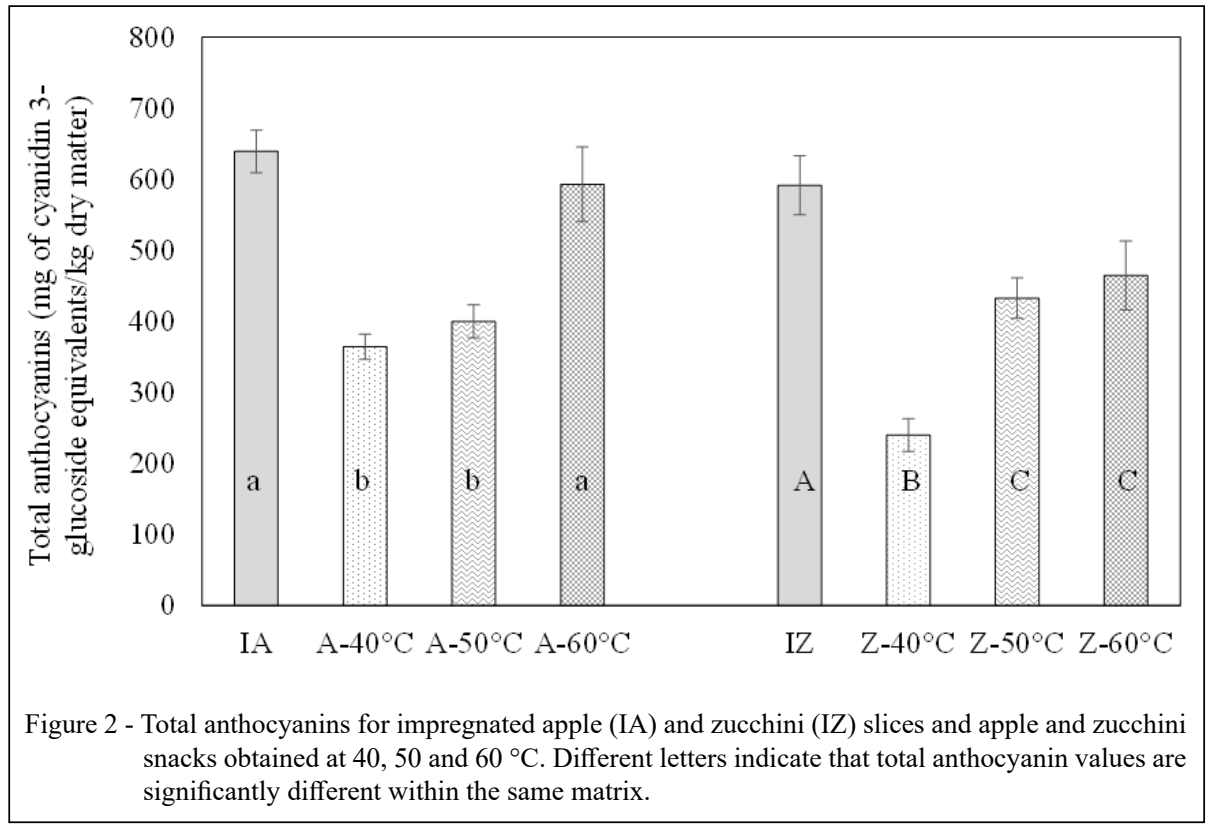

slices impregnated with blueberries juice at 40, 50 and $60{ }^{\circ} \mathrm{C}$. The Page model was the most adequate for the experimental data. When dehydration temperature was $60{ }^{\circ} \mathrm{C}$, a snack with a higher content of anthocyanins and shorter dehydration times was obtained. The combination of vacuum impregnation and hot air drying represented an effective technological alternative to produce snacks, contributing to add value to apples and zucchinis.

\section{ACKNOWLEDGMENTS}

This research was supported by the Universidad Nacional de Entre Ríos though the research project titled "PID-UNER: 8068: Diseño de jugo de arándanos con propiedades antioxidants y probióticas".

\section{DECLARATION OF CONFLICT OF INTERESTS}

The authors declare no conflict of interest. The founding sponsors had no role in the design of the study; in the collection, analyses, or interpretation of data; in the writing of the manuscript, and in the decision to publish the results.

\section{AUTHORS' CONTRIBUTIONS}

All authors contributed equally for the conception and writing of the manuscript. All authors critically revised the manuscript and approved of the final version.

\section{REFERENCES}

AOAC. Association of official analytical chemists Washington, DC. USA Official methods of analysis, 18th ed.,
2010. Available from: <https://www.aoac.org/>. Accessed: Aug. 13, 2018.

BAHMANI, A. et al. Mass transfer kinetics of eggplant during osmotic dehydration by neural networks. Journal of Food Processing and Preservation, [s.1.], v.40, n.5, p.815-827, 2016. Available from: <http://doi.wiley.com/10.1111/jfpp.12435>. Accessed: Aug. 13, 2018. doi: 10.1111/jfpp.12435.

CASTAGNINI, J. M. et al.. Multiple response optimization of blueberry juice depectinization. Ciencia Rural, 47(4), 1-9. 2017. Available from: <https://doi.org/10.1590/0103-8478cr20160501>. Accessed: Aug. 1, 2018. doi: 10.1590/0103-8478cr20160501.

CORZO, O. et al. Weibull distribution for modeling air drying of coroba slices. LWT - Food Science and Technology, [s.1.], v.41, n.10, p. 2023-2028, 2008. Available from: <https://doi. org/10.1016/j.lwt.2008.01.002>. Accessed: Aug. 1, 2018. doi: 10.1016/j.lwt.2008.01.002.

COSTA, B. R. et al. Optimization of spirulina sp. drying in heat pump: effects on the physicochemical properties and color parameters. Journal of Food Processing and Preservation, [s.1.], v.40, n.5, p.934-942, 2016. Available from: <http://doi.wiley.com/10.1111/ jfpp.12672>. Accessed: Aug. 1, 2018. doi: 10.1111/jfpp.12672.

CRANK, J. The mathematics of diffusion. [s.1.]: Oxford university press, 1979.

DEĞIRMENCIOĞLU, N. et al. Influence of hot air drying on phenolic compounds and antioxidant capacity of blueberry (Vaccinium myrtillus) fruit and leaf. Journal of Applied Botany and Food Quality, [s.1.], v.90, p.115-125, 2017. Available from: $<$ https://doi.org/10.5073/JABFQ.2017.090.014>. Accessed: Aug. 1, 2018. doi: 10.5073/JABFQ.2017.090.014.

DI SCALA, K. et al. Drying kinetics and quality changes during drying of red pepper. LWT - Food Science and Technology, 
[s.1.], v.41, n.5, p.789-795, 2008. Available from: $<$ https://doi. org/10.1016/j.lwt.2007.06.007>. Accessed: Aug. 1, 2018. doi: 10.1016/j.lwt.2007.06.007.

PUENTE-DÍAZ, L. et al. Combined infrared-convective drying of murta (Ugni molinae Turcz) berries: kinetic modeling and quality assessment. Drying Technology, 31(3), 329-338, 2013. Available from: <https://doi.org/10.1080/07373937.2012.736113 >. Accessed: Aug. 1, 2018. doi: 10.1080/07373937.2012.736113.

DOYMAZ, I. et al. Characteristics of thin-layer infrared drying of green bean. Czech Journal of Food Sciences, [s.1.], v.33, n.No. 1, p.83-90, 2016. Available from: <https://doi. org/10.17221/423/2014-CJFS $>$. Accessed: Aug. 13, 2018. doi: 10.17221/423/2014-CJFS.

JUNQUEIRA, J. R. - J. et al. Microwave, convective, and intermittent microwave-convective drying of pulsed vacuum osmodehydrated pumpkin slices. Journal of Food Processing and Preservation, [s.l.], v.41, n.6, p.e13250, 2017. Available from: $<$ http://doi.wiley.com/10.1111/jfpp.13250>. Accessed: Aug. 13, 2018. doi: 10.1111/jfpp.13250.

LÓPEZ, J. et al. Effect of air temperature on drying kinetics, vitamin $\mathrm{C}$, antioxidant activity, total phenolic content, nonenzymatic browning and firmness of blueberries variety $\mathrm{O}^{\prime} \mathrm{Neil}$. Food and Bioprocess Technology, [s.1.], v.3, n.5, p.772-777, 2010. Available from: $<$ https://doi.org/10.1007/s11947-009-03068>. Accessed: Apr. 15, 2013. doi: 10.1007/s11947-009-0306-8.

MARTELO C, Y. et al. Dinámica de impregnación al vacío en apio (Apium graveolens L.) y pepino (Cucumis sativus L.). Revista MVZ Córdoba, [s.1.], v.16, n.2, p.2584, 2011. Available from: $<$ http://revistas.unicordoba.edu.co/index.php/revistamvz/article/ view/1031>. Accessed: Aug. 1, 2018.

OLANIPEKUN, B. F. et al. Mathematical modeling of thin-layer pineapple drying. Journal of Food Processing and Preservation, [s.1.], v.39, n.6, p.1431-1441, 2014. Available from: <https://doi.org/10.1111/ jfpp.12362>. Accessed: Aug. 13, 2018. doi: 10.1111/jfpp.12362.

PEREIRA KECHINSKI, C. et al. Degradation kinetics of anthocyanin in blueberry juice during thermal treatment. Journal of Food Science, [s.1.], v.75, n.2, p.C173-C176, 2010. Available from: $<$ https://doi.org/10.1111/j.1750-3841.2009.01479.x>. Accessed: Apr. 20, 2013. doi: 10.1111/j.1750-3841.2009.01479.x.
PERON, D. V. et al. Thermal degradation kinetics of anthocyanins extracted from juçara (Euterpe edulis Martius) and "Italia" grapes (Vitis vinifera L.), and the effect of heating on the antioxidant capacity. Food Chemistry, [s.1.], v.232, p.836-840, 2017. Available from: <http://dx.doi.org/10.1016/j. foodchem.2017.04.088>. Accessed: Aug. 13, 2018. doi: 10.1016/j.foodchem.2017.04.088

SOUSA-DUTRA, A. et al. Drying kinetics and effect of airdrying temperature on chemical composition of Phyllanthus amarus and Phyllanthus niruri. Drying Technology, [s.1.], v.36, n.5, p.609-616, 2018. Available from: <https://doi.org/10.10 80/07373937.2017.1351454>. Accessed: Aug. 13, 2018. doi: 10.1080/07373937.2017.1351454.

TAGHIAN DINANI, S. et al. Mathematical modeling of hot air/electrohydrodynamic (EHD) drying kinetics of mushroom slices. Energy Conversion and Management, [s.1.], v.86, p.70-80, 2014. Available from: <https://doi.org/10.1016/j. enconman.2014.05.010>. Accessed: Aug. 1, 2018. doi: 10.1016/j. enconman.2014.05.010.

TUNÇKAL, C. et al. Determination of sliced pineapple drying characteristics in a closed loop heat pump assisted drying system. International Journal of Renewable Energy Development, [s.1.], v.7, n. 1, p.35, 2018. Available from: <https://doi. org/10.14710/ijred.7.1.35-41>. Accessed: Aug. 13, 2018. doi: 10.14710/ijred.7.1.35-41.

VEGA-GÁLVEZ, A. et al. kinetic study of convective drying of blueberry variety O'Neil (Vaccinium corymbosum L.). CHILEAN JOURNAL OF AGRICULTURAL RESEARCH, [s.1.], v.69, n.2, p.171-178, 2009. Available from: <http://www.bioline.org.br/ pdf?cj09020>. Accessed: Aug. 1, 2018.

VEGA-GÁLVEZ, Antonio et al. effect of selected pretreatments on convective drying process of blueberries (var. O'Neil). Food and Bioprocess Technology, [s.1.], v.5, n.7, p.2797-2804, 2012. Available from: <https://doi.org/10.1007/s11947-011-0656-x>. Accessed: Aug. 1, 2018. doi: 10.1007/s11947-011-0656-x.

ZHAO, Xiaoyan et al. Composition and thermal stability of anthocyanins from chinese purple corn (Zea mays L.). Journal of Agricultural and Food Chemistry, [s.1.], v.56, n.22, p.1076110766, 2008. Available from: <https://doi.org/10.1021/jf8025056>. Accessed: Aug. 13, 2018. doi: 10.1021/jf8025056. 